\title{
GRANICE PRAWNE BOJKOTU W RELACJACH GOSPODARCZYCH
}

Uczciwa konkurencja stanowi bezspornie przejaw istnienia i funkcjonowania racjonalnej gospodarki rynkowej. To dzięki niej konkurujące podmioty gospodarcze zmuszone sa oferować klientom coraz to nowsze, a co przy tym najistotniejsze, znacznie atrakcyjniejsze towary i usługi. W procesie tym dochodzi zatem do kreowania różnych działań konkurencyjnych. Nie zawsze mają one charakter uczciwy. Znamiennym tego przykładem jest bojkot określonych przedsiębiorców. Czyn ten stwarza poważne ryzyko blokowania prowadzenia działalności gospodarczej i co się z tym niekiedy wiąże, utrudniania dostępu do rynku. Stąd też celem niniejszego artykułu jest analiza granic prawnych, których przekroczenie umożliwia kwalifikację prawną określonych czynów jako noszących znamiona bojkotu. Kwalifikacja ta ma zostać dokonana na tle stosunków gospodarczych zachodzących pomiędzy przedsiębiorcami.

\section{WPROWADZENIE}

Jakkolwiek instytucja prawna bojkotu jest aprobowana przez dominujacy nurt doktryny i orzecznictwa, a przy tym uważana za potrzebna, jej precyzyjna kwalifikacja prawna oparta na doświadczeniach życia codziennego może budzić uzasadnione wattpliwości. Podstawowy problem związany z jednoznacznym ustaleniem normatywnych granic czynu zwanego „bojkotem” wynika z różnych jego przejawów i szerokiego wymiaru. Nie jest przecież tajemnica, że współczesne bojkoty przedsiębiorców, produktów lub usług mogą mieć charakter spontanicznych akcji społecznych, które prowadzone są w mediach społecznościowych. Fikcyjne bojkoty społeczne mogą być w tym ujęciu inspirowane przez konkurencyjnych przedsiębiorców, wynajęte przez nich agencje albo inne podmioty. Nie można także pominąć przejawów bojkotu zmierzajacych do ochrony określonych wartości (ochrona środowiska, ochrona zwierząt, zwalczanie wyzysku itp.). Bojkot może ponadto znaleźć swoje odzwierciedlenie w wymiarze politycznym czy towarzyskim. Część badaczy uważa, że pewne formy bojkotu, takie jak bojkot z przyczyn politycznych czy społecznych, znajduja się poza zakresem problematyki zjawisk konkurencji ${ }^{1}$. Na przeciwległym

${ }^{1}$ Mioduszewski, Sroczyński (2016): 672. 
skrzydle ukształtowało się jednak stanowisko, zgodnie z którym stosowanie środków o charakterze politycznym może również skutkować naruszeniem konkurencji na wspólnym rynku, w tym prowadzić do bojkotu².

Kwestią otwartą i sporna pozostaja zwłaszcza bojkoty opierające się na przesłankach gospodarczych. To właśnie bojkot zachodzący w stosunkach gospodarczych stanowi najdoskonalszy przykład kategorii, która odpowiada ściśle regulacjom zawartym w przepisach ustawy z 16 kwietnia 1993 r. o zwalczaniu nieuczciwej konkurencji ${ }^{3}$. Należy wszakże z naciskiem podkreślić, że nawet bojkoty gospodarcze stanowią jedynie marginalną część tego zjawiska, niezależnie od ich wymiaru gospodarczego i prawnego. Jednocześnie z uwagi na charakter, a ściśle rzecz ujmując, niekwestionowany wpływ na relacje zachodzace pomiędzy podmiotami gospodarczymi, warto przyjrzeć się bliżej przesłankom charakteryzujacych ten typ bojkotu.

Trudności w obiektywnej weryfikacji bojkotu gospodarczego wynikaja między innymi z dopuszczalności tzw. dozwolonej krytyki. W związku z tym faktem wyłącznie werbalna wykładnia pozwala bronić poglądu, że wyrażenie swojej opinii na temat innego przedsiębiorcy miałoby stanowić każdorazowo przejaw bojkotu. Brak podstaw do aprobaty tego poglądu wynika wprost z art. 15 ust. 1 pkt 2 u.z.n.k. Stosownie bowiem do zakodowanej w nim treści normatywnej czynem nieuczciwej konkurencji jest utrudnianie innym przedsiębiorcom dostępu do rynku, w szczególności przez nakłanianie osób trzecich do odmowy sprzedaży innym przedsiębiorcom albo niedokonywania zakupu towarów lub usług od innych przedsiębiorców. Opierając się zatem na wykładni teleologicznej tego przepisu, dany przedsiębiorca może w ramach odpowiedniej argumentacji dowodzić braku ziszczenia się przesłanek zakazanego nakłaniania do bojkotowania innego podmiotu gospodarczego. Może też próbować wykazać, że każdy ma prawo do dozwolonego rozpowszechniania określonych informacji, które nie wyczerpują znamion czynu nieuczciwej konkurencji.

Przedstawione wyżej kontrowersje uzasadniaja przeprowadzenie gruntownej analizy, której celem jest wyjaśnienie, czy aktualnie obowiąujący art. 15 ust. 1 pkt 2 u.z.n.k. pozwala na jednoznaczne wskazanie granicy, kiedy określone działania przekraczają ramy uczciwego konkurowania. W szczególności chodzi o funkcjonalne zbadanie zjawiska bojkotu na tle relacji gospodarczych zachodzących pomiędzy różnymi podmiotami gospodarczymi.

\section{CZYNNOŚĆ PRAWNA BOJKOTU - ISTOTA ZJAWISKA}

Praktyczna doniosłość art. 15 ust. 1 pkt 2 u.z.n.k. powinna znaleźć swój wyraz w przeciwdziałaniu czynnościom nakłaniania do odmowy sprzedaży, albo niedokonywania zakupu określonych dóbr i usług u innych przedsiębiorców. Pierwszym krokiem zmierzajacym do ustalenia, czy w praktyce obrotu

\footnotetext{
2 Nykiel-Mateo (2009): rozdz. III.1.3.4.

3 T.jedn.: Dz. U. 2019, poz. 1010 (dalej jako: u.z.n.k.).
} 
gospodarczego komentowany przepis spełnia taką funkcję, jest ustalenie istoty zjawiska bojkotu. Wśród postulatów definiujących bojkot najtrafniejszy wydaje się ten, że jest to forma zachowania rynkowego polegającego na zbiorowej odmowie wchodzenia w stosunki gospodarcze $\mathrm{z}$ innym przedsiębiorca przez klientów lub przedsiębiorców z klientami ${ }^{4}$. W celu wykazania zasadności postawionej tezy podnosi się, że bezpośrednim skutkiem tego działania jest ekonomiczne ograniczenie lub całkowite wyeliminowanie możliwości działania przez jego adresatów na rynku, co prowadzi do zerwania więzi gospodarczych i przekłada się częstokroć na niedostrzegalną izolację określonych uczestników obrotu ${ }^{5}$. Istnieją także głosy zwolenników koncepcji opowiadającej się za kwalifikacją bojkotu jako formy „wdzierania się w klientelę konkurenta”.

Zbliżone stanowisko w sprawie bojkotu zajmuje judykatura. W myśl tezy przytoczonej w wyroku z Sądu Apelacyjnego w Łodzi ${ }^{7}$ : ,zachowanie takie jest $\mathrm{w}$ istocie zawsze działaniem zorganizowanym, poprzedzonym jakiegoś rodzaju porozumieniem. W sferze wykonawczej jest to zespół skoordynowanych, indywidualnych dyskryminacji o odpowiednim przedmiocie, skierowanych przeciwko temu samemu przedsiębiorcy lub przedsiębiorcom. Przepis 15 ust. 1 pkt 2 u.z.n.k. określa bojkotujących jako osoby trzecie. Mogą to być zatem zarówno przedsiębiorcy występujący w roli klientów, jak i konsumenci, organizacje społeczne itp. Ważne jest, aby osoby te miały możliwość kolektywnego wpływania na sytuację gospodarczą bojkotowanego".

Jak wywodzi się w piśmiennictwie, celem bojkotu gospodarczego z art. 15 u.z.n.k. jest uniemożliwienie lub ograniczenie konkurentowi możliwości udziału w stosunkach handlowych, tymczasem ustawa ta nie wskazuje żadnej szczególnej przesłanki nieuczciwości nakłaniania do bojkotu. Brak w niej w szczególności wymogu, aby nakłanianie do bojkotu miało na celu osiagnięcie korzyści ekonomicznych czy eliminację innych przedsiębiorców (tak jak w art. 15 ust. 1 pkt 1 u.z.n.k.), dlatego zakres stosowania tego przepisu zależy od sądowej interpretacji art. 3 u.z.n.k., zwłaszcza sprzeczności z dobrymi obyczajami w odniesieniu do sytuacji nakłaniania do bojkotu. W związku z powyższym sąd będzie więc musiał odpowiedzieć na pytanie, czy bojkot jest sprzeczny z dobrymi obyczajami ze względów zwyczajowych, społecznych, politycznych bądź światopoglądowych ${ }^{8}$.

Na gruncie prawa konkurencji podnosi się, że z bojkot występuje na przykład w sytuacji nakłania do zrezygnowania z umieszczania reklam u konkurenta (oczywiście pod warunkiem, że nakłanianie takie będzie sprzeczne z dobrymi obyczajami $)^{9}$. W innym jeszcze ujęciu bojkot oznacza działanie podejmowane w celu izolowania kogoś od otoczenia, przymuszanie do zerwania stosunków ekonomicznych, prawnych i społecznych (np. przez zachęcenie klientów i konsumentów wymienionego pracodawcy do zaprzestania kupowa-

\footnotetext{
${ }^{4}$ Por. Mioduszewski, Sroczyński (2016): 672.

5 Mioduszewski, Sroczyński (2016): 672.

${ }^{6}$ Tak wyraźnie: Skoczny, Bernatt (2016): 546.

7 Wyrok SA w Łodzi z 13 grudnia 2018 r., I AGa 256/18, Lex nr 2625546.

8 Tak Dominowska (2013): 90.

${ }_{9}$ Nowińska, du Vall (2005).
} 
nia produkowanych przez niego towarów lub korzystania z oferowanych przez niego usług) ${ }^{10}$.

Odnosząc się do stanowiska doktryny i orzecznictwa, wyrażam pogląd, że bojkot w relacjach gospodarczych oznacza świadome podjęcie nieuczciwych działań przez innych przedsiębiorców o charakterze zorganizowanej ogólnej zmowy, których celem i skutkiem jest doprowadzenie do stanu „pozornej” dostępności przez bojkotowanego przedsiębiorcę do określonych dóbr i usług, o czym może on nawet nie wiedzieć. Jednakże z uwagi na ukryty lub nawet jawny charakter „nakłaniania” możliwości uczciwego konkurowania, a w tym oferowania towarów i usług przez bojkotowanego przedsiębiorcę, zwłaszcza z perspektywy zdolności przyciagania przez niego klienteli, sa co najmniej ograniczone. Rozwijając tę myśl, w przypadku bojkotu faktycznym problemem pozostaje nie wzajemne przejmowanie klienteli, co jest zjawiskiem naturalnym w gospodarce rynkowej, lecz ustalenie, kiedy efekt taki zostanie osiagnięty nieuczciwie. Konkludując - ziszczenie się przesłanek bojkotu w relacjach gospodarczych należy przede wszystkim oceniać z punktu widzenia zasad nieuczciwej konkurencji, których granice wskazuje wyraźnie art. 3 u.z.n.k.

\section{PODMIOTY BOJKOTUJĄCE}

Istotnym problemem w zakresie ustalenia przejawów bojkotu pozostaje strona podmiotowa tego zjawiska. W największym uproszczeniu chodzi o to, kto może dopuścić się tego czynu. Zdaniem części przedstawicieli doktryny, bojkot może wystapić zarówno po stronie popytu (niedokonywanie zakupu), jak i podaży (odmowa sprzedaży), przy czym w procesie tym uczestniczą zwykle trzy podmioty, a zatem: przedsiębiorca nakłaniajacy do bojkotu, podmiot bojkotujacy oraz przedsiębiorca bojkotowany ${ }^{11}$. Podzielając ten pogląd, wypada dodać, że oceny przedmiotowej, czy brak popytu i podaży jest skutkiem czynności bojkotu, należy dokonywać według reguł logiki, doświadczenia życiowego i natury społeczno-gospodarczej.

W polskim piśmiennictwie dominuje jednolita koncepcja podmiotu bojkotującego. Zgodnie zatem z przeważającym poglądem podmiotem nakłaniającym do bojkotu może być wyłącznie co najmniej jeden przedsiębiorca obok naruszającego, w tym nawet pośrednio, gdy dokonuje tej czynności przy pomocy innych podmiotów, co jednak i tak nie zwalnia go od poniesienia odpowiedzialności ${ }^{12}$. Przekonująco dowodzi się zarazem w orzecznictwie, że definicja bojkotu wymaga istnienia po stronie bojkotującego co najmniej dwóch podmiotów, wśród których może być także sam nakłaniający do bojkotu przedsiębiorca. Stąd bojkotu nie można więc prowadzić w konfiguracji jednopodmiotowej po

10 Żołyński (2012): nb. 6.

11 Tak Nowińska (2014): 352; Nowińska, Szczepanowska-Kozłowska (2018): 328; Mioduszewski, Sroczyński (2016): 674-675.

12 Por. Nowińska (2014): 352; Skoczny, Bernatt (2016): 547-548; Kępiński (2001): teza 3. 
stronie bojkotującego ${ }^{13}$. Stanowisko zbliżone do powyższego zawiera się też w opinii, że bojkotować mogą również klienci konkurenta (osoby fizyczne, organy publiczne, organizacje konsumenckie, partie polityczne), nakłonieni do tego przez przedsiębiorcó $\mathrm{w}^{14}$.

Węzłowym założeniem tak przyjętego kierunku interpretacji jest pogląd o dopuszczalności nieuczciwego nakłaniania do bojkotu przez grupę przedsiębiorców ${ }^{15}$. Podzielając to stanowisko, uważam, że wskazany argument jest kluczowy z punktu widzenia udowodnienia ciężaru i rozmiarów winy, ponieważ wiąże się ze znacznie większą szkodą dla bojkotowanego, niż gdyby bojkotu dokonywał wyłacznie jeden podmiot gospodarczy ${ }^{16}$.

$\mathrm{Na}$ gruncie odrębnej argumentacji osobami trzecimi muszą być bezwarunkowo podmioty niezależne od nakłaniającego, co uzasadnia się niedopuszczalnością zastosowania art. 15 u.z.n.k. w sytuacji, gdy bojkotujący pozostaje w stosunku zależności wobec nakłaniającego do bojkotu ${ }^{17}$. Podobnie też ujmuje to pogląd, że w relacjach pomiędzy przedsiębiorcami, gdy brak wyraźnie wskazanego wyjątku, sprawcami bojkotu nie mogą być pracownicy przedsiębiorcy lub konsumenci i organizacje, partie polityczne, organizacje społeczne w zakresie, w jakim nie występują jako przedsiębiorcy ${ }^{18}$.

Przytoczone poglądy nakazują zając stanowisko, że podmiotem nakłaniającym do bojkotu w relacjach gospodarczych musi być zawsze przedsiębiorca. Dokonuje tego osobiście albo przy pomocy innych osób (podmiotów), które nie moga jednak pozostawać z nim w jakimkolwiek związku zależności. Niezbędną przesłanką ziszczenia się bojkotu jest przy tym istnienie wzajemnej relacji co najmniej dwóch podmiotów, tj. tego, który nakłania do bojkotu lub bojkotuje wobec innego podmiotu. Ten ostatni może w następstwie tych czynności również nakłaniać lub bojkotować. Ostatecznie bojkot może wynikać z działań grupy przedsiębiorców nakłaniających do bojkotu lub bojkotujących.

\section{BOJKOT W RELACJACH GOSPODARCZYCH}

Wzajemne relacje gospodarcze mogą zachodzić pomiędzy podmiotami już istniejacymi na rynku. Brak jednak podstaw, aby twierdzić, że relacje gospodarcze mogą mieć również charakter abstrakcyjny. Obejmuje to przypadki zachodzące pomiędzy osobami, które dopiero mają zamiar uzyskać status przedsiębiorcy. Z tego względu kluczową problematyka, którą warto w tym

${ }^{13}$ Zob. powołany już wyżej wyrok SA (2018): I AGa 256/18.

${ }^{14}$ Stanowisko takie prezentuja: Skoczny, Bernatt (2016): 547-549; Nowińska, Szczepanowska-Kozłowska (2018): 328. Odmiennie Walaszek-Pyzioł, Pyzioł (1994): 6.

${ }_{15}$ Zob. orzeczenie SN z 20 maja 1932 r., I C 2564/31, OSN(C) 1932, nr 1, poz. 111.

${ }^{16}$ SN Stanów Zjednoczonych Ameryki Północnej w sprawie Northwest Wholesale Stationers, Inc. V Pacific Stationery and Printing Co. 472 U.S. 284 (1985) wyraził pogląd, że bojkot grupowy jest zakazany wyłącznie wtedy, gdy nie prowadzi do zwiększania efektywności działania.

17 Skoczny, Bernatt (2016): 549.

18 Zob. np. Nowińska, du Vall (2008): 187. 
momencie omówić, jest kwestia tego, w jakiej mierze ustawodawca wiąże w art. 15 ust. 1 pkt 2 u.z.n.k. wzajemne relacje gospodarcze pomiędzy podmiotami funkcjonującymi i niefunkcjonującymi jeszcze na rynku ze zjawiskiem bojkotu.

W tym zakresie trzeba przyznać rację zwolennikom poglądu, że bojkot może przybrać dwojaka postać. W pierwszym przypadku bojkot będzie miał bowiem za zadanie utrudnienie wykonywania działalności gospodarczej przez odciagnięcie kontrahentów od bojkotowanego, w drugim z kolei - odizolowanie ich od niego lub skłonienie do rezygnacji z przygotowań do zawarcia transakcji handlowych ${ }^{19}$. W orzecznictwie panuje daleko posunięta zbieżność opinii co do tego, że sprawca bojkotu nie musi pozostawać w bezpośrednim stosunku konkurencji z bojkotowanym, a dla ziszczenia się przesłanek bojkotu wystarczy istnienie nawet potencjalnej zdolności do wpływania przez niego na sytuację rynkowa ${ }^{20}$. Reprezentowany jest także pogląd, że strony nie musi łączyć żaden stosunek prawny ${ }^{21}$, nakłanianie zaś musi być świadome i zamierzone w celu wywołania pożądanej przez nakłaniającego reakcji ${ }^{22}$. Zwolennicy tego stanowiska zakładają również w stosunku do bojkotu gospodarczego brak konieczności ziszczenia się przesłanki posiadania władzy rynkowej, a co więcej, czynu takiego może się dopuścić nawet podmiot, który faktycznie nie jest w stanie wywołać zamierzonego skutku ${ }^{23}$.

W tej kwestii na szczególne uznanie zasługuje pogląd, że bojkot może mieć charakter jednorazowej, a przy tym kolektywnej odmowy do działania powtarzalnego albo nawet ciagłego ${ }^{24}$. Stąd znaczenie nawet jednorazowej transakcji, która stała się przedmiotem bojkotu, biorąc pod uwagę całokształt okoliczności, a w tym jej wartość, rodzaj i czas, w jakim ma zostać zrealizowana, może być bardzo duże. W związku z tym skuteczny bojkot może wyeliminować czasowo lub trwale zdestabilizować rynkową pozycję dotkniętego nim przedsiębiorcy $^{25}$.

Wobec wymowy przedstawionych argumentów należy dojść do wniosku, że praktyczne trudności związane z próbami zdefiniowania, a nawet wyjaśnienia istoty zjawiska bojkotu w relacjach gospodarczych, ujawniają się na tle tego, że nawet w stanach faktycznych, w których na ogół przyjmuje się zwykle popełnienie tego czynu, ustawa przewiduje dla takiego stwierdzenia ziszczenie się chociażby jednorazowej przesłanki nieuczciwego „nakłaniania”. Ustawodawca uzależnia ponadto ziszczenie się przesłanki bojkotu we wzajemnych relacjach gospodarczych pomiędzy podmiotem bojkotującym i bojkotowanym od posiadania statusu przedsiębiorcy (argument z art. 15 ust. 1 pkt 2 u.z.n.k., gdzie

19 Tak Mioduszewski, Sroczyński (2016): 674.

20 Zob. orzeczenie SN z 17 czerwca 2004 r., V CK 550/03, Monitor Prawniczy 2004, nr 14, poz. 631, oraz SA we Wrocławiu z 21 października 2004 r., I ACa 546/04, Lex nr 519264.

21 Zob. Nowińska (2014): 352; Nowińska, Szczepanowska-Kozłowska (2018): 328; Mioduszewski, Sroczyński (2016): 674.

22 Tak np. Nowińska (2014): 352.

23 Szerzej Nowińska (2014): 352; Nowińska, Szczepanowska-Kozłowska (2018): 331.

${ }^{24}$ Zob. Mioduszewski, Sroczyński (2016): 673.

25 Mioduszewski, Sroczyński (2016): 673. 
wyraźnie mowa o przedsiębiorcach). W taki bowiem tylko sposób można interpretować zjawisko izolacji przedsiębiorców w relacjach gospodarczych. Opierając się jednak na wykładni dynamicznej, można bronić poglądu, że sama już tylko zdolność do bojkotowania może wyrządzić znaczące szkody osobom, które jeszcze nie funkcjonują na rynku, ale podjęły działania w tym kierunku. Trudno zaprzeczyć, że również takie „byty faktyczne” mogą być bojkotowane. Rozstrzygnięcie ustawowe, że w relacjach gospodarczych bojkot może wywierać skutek wyłącznie pomiędzy podmiotami gospodarczymi, przesądza o wyłączeniu z art. 15 ust. 1 pkt 2 u.z.n.k. „nieprzedsiębiorców”. W stosunku do osób nieposiadających statusu przedsiębiorców, które czują się bojkotowane, przewidziano możliwość skorzystania $\mathrm{z}$ ochrony na podstawie przepisów ustawy z 23 sierpnia 2007 r. o przeciwdziałaniu nieuczciwym praktykom rynkowym ${ }^{26}$. Ze względu jednak na fakt, że celem niniejszego artykułu jest analiza przesłanek bojkotu mających miejsce wyłącznie w stosunku do przedsiębiorców, powyższa materia zostanie pominięta.

W świetle dokonanych ustaleń trzeba stwierdzić, że na gruncie art. 15 ust. 1 pkt 2 u.z.n.k. uzależnia kwalifikację prawną bojkotu w relacjach gospodarczych, jako czynu nieuczciwej konkurencji, od posiadania statusu przedsiębiorcy. Zgodnie z poglądami doktryny i judykatury dla stwierdzenia przesłanki bojkotu w relacjach gospodarczych pomiędzy przedsiębiorcami nie ma żadnego znaczenia wzajemny stosunek konkurencji, stosunek prawny, pozycja na ryn$\mathrm{ku}$ ani okres wzajemnych relacji. Jest to dobry kierunek interpretacji, gdyż inna wypaczałaby istotę bojkotu, uzależniając skorzystanie $\mathrm{z}$ dobrodziejstwa tej instytucji w relacjach gospodarczych od ziszczenia się innych, dodatkowych i niepotrzebnych przesłanek.

\section{PRZESLANKA NIEUCZCIWEGO NAKLANIANIA}

Brak zdefiniowania przez ustawodawcę konstrukcji „nakłaniania” wymusza potrzebę poszukiwania $\mathrm{w}$ stanowisku doktryny i judykatury remedium, które ma służyć celom zapobiegania i usuwania rażących skutków naruszenia przepisów ustawy o zwalczaniu nieuczciwej konkurencji ${ }^{27}$. W tym zakresie wyrażono pogląd, że nie jest przejawem bojkotu rozpowszechnianie rzetelnych i prawdziwych informacji, uzyskanych bez wywierania nacisku psychologicznego, które mieszczą się w ramach powszechnie zagwarantowanej konstytucyjnie wolności słowa ${ }^{28}$. Przeciwstawne tendencje do tego poglądu można zaobserwować w wywodzie, w którym krytykuje się znikome znaczenie praktyczne tez tam zawartych, a to ze względu na trudność w oddzieleniu zachowań dozwolonych od zakazanych. Z tego powodu proponuje się przeprowadzenie „testu prawdy”, który miałby polegać na dopuszczalności kolportowania prawdziwych informacji o produktach mogących wprawdzie wywołać skutek

\footnotetext{
${ }^{26}$ T.jedn.: Dz. U. 2017, poz. 2070 ze zm.

${ }^{27}$ Jak wskazuje definicja słownikowa - nakłanianie oznacza zachęcanie kogoś do czegoś, namawianie, przekonywanie. Zob. <https://sjp.pl/nak\%C5\%82ania\%C4\%87> [dostęp: 2.02.2019].

${ }^{28}$ Zob. m.in. Mioduszewski, Sroczyński (2016): 677; Skoczny, Biernat (2016): 550.
} 
w postaci zmniejszonej sprzedaży, co jednak nie stanowi przejawów bojkotu $\mathrm{w}$ przeciwieństwie do rozpowszechniania informacji prawdziwych, ale niemających zwiąku ze sprzedawanymi produktami ${ }^{29}$.

Istotę toczącej się polemiki dobrze obrazuje również stanowisko wywodzące brak przesłanek bezprawności działania w przypadku, gdy jego celem jest obrona przed sprzecznym z prawem lub dobrymi obyczajami zachowaniami innych przedsiębiorców, jeżeli brak jest alternatywnych środków obrony i zachowana została zasada proporcjonalności ${ }^{30}$. W tym kontekście na uznanie zasługuje trafna opinia, zgodnie z którą odmowa współpracy z przedsiębiorca sama w sobie nie stanowi czynu nieuczciwej konkurencji ${ }^{31}$.

Najpełniej istotę zjawiska nakłaniania do bojkotu oddaje teza, według której przez to pojęcie należy rozumieć „wywieranie na kogoś wpływu za pomocą różnych środków i technik w celu wywołania u innej osoby jakiegoś zachowania. Osoba, którą udało się nakłonić, nie zawsze jest osobą przekonana, może jedynie ulec nakłaniającemu dzięki sile jego perswazji, często wynikającej z faktycznej przewagi rynkowej lub renomy. Nakłanianie jako czynność sprawcza samo w sobie nie zakłada skuteczności podejmowanych działań, a więc doprowadzenia do tego, że nakłaniany wykona określone czynności będące treścią nakłaniania. Na gruncie powołanego przepisu wystarczy, żeby przedsiębiorca przedsięwziął środki służące wywieraniu takiego wpływu na osoby trzecie i zaznaczył w treści swoich przekazów swoja wolę sprawienia, aby inne osoby zachowały się w oczekiwany przez niego sposób, ze szkodą dla swobody prowadzenia działalności gospodarczej innego podmiotu. Środki te oczywiście musza być chociażby potencjalnie zdolne do wywołania określonego skutku" ${ }^{2}$. W piśmiennictwie sformułowano ponadto postulat, że nakłanianie do określonego zachowania, zgodnego z wolą nakłaniającego, stanowi jedna z przesłanek nie tylko czynu nieuczciwej konkurencji opisanego w art. 15 ust. 1 pkt 2 , lecz również czynów unormowanych w art. 12 ust. 1 i 2 . Różnica pomiędzy działaniami objętymi hipotezą art. 15 ust. 1 pkt 2 a określona w art. 12 ust. 2 polega przede wszystkim na tym, że z bojkotem (art. 15 ust. 1 pkt 2) mamy do czynienia w tych sytuacjach, gdy podmiotu bojkotowanego nie łączą z podmiotem bojkotujacym stosunki prawne (dotyczące przedmiotu ewentualnej transakcji). Tymczasem hipotezą art. 12 ust. 2 objęte sa przypadki, gdy między tymi podmiotami stosunek taki istnieje $\mathrm{e}^{33}$.

W kontekście przedstawionych uwag ważnym i o doniosłym znaczeniu praktycznym jest zagadnienie, w jakich przypadkach nie dochodzi do nakłaniania do bojkotu. Według jednego z poglądów wspólne uzgadnianie z osobami trzecimi określonej strategii gospodarczej (np. w zakresie umów na wyłączność) czy zaopatrywanie się we wspólne surowce nie jest nakłanianiem do

\footnotetext{
29 Tak m.in. Nowińska (2014): 353; Nowińska, Szczepanowska-Kozłowska (2018): 329.

${ }^{30}$ Zob. szerzej: Skoczny, Bernat (2016): 550.

31 Orzeczenie SA we Wrocławiu z 19 listopada 2008 r., I ACa 940/08, Lex nr 519248.

32 Zob. uzasadnienie wskazanego wyżej wyroku (2018): I Ga 256/18.

${ }^{33}$ Nowińska, Szczepanowska-Kozłowska (2018): 330-331.
} 
bojkotu $^{34}$. Referowana linia obrony znajduje wyraz w twierdzeniu, że nakłanianie klientów do niedokonywania zakupu określonych towarów u konkurenta, lecz u siebie (tzn. u nakłaniajacego) nie jest objęte hipoteza art. 15 ust. 1 pkt 2, chociaż w konkretnych okolicznościach postępowanie takie może stanowić inny czyn nieuczciwej konkurencji, w szczególności niedozwoloną reklamę porównawczą lub naruszenie renomy kontrahenta ${ }^{35}$. Autorzy wtórujący temu stanowisku dowodzą zarazem, że nie zawsze rozpowszechnianie nieprawdziwych lub wprowadzających w błąd informacji musi stanowić zachętę do podjęcia przez osoby trzecie określonych działań w celu kolektywnego zdestabilizowania sytuacji rynkowej przedsiębiorcy, o którym mowa w art. 15 ust. 1 pkt 2 u.z.n.k. ${ }^{36}$

Rozważania niniejsze byłyby niepełne, gdyby nie omówiono zagadnienia, czy nakłanianie do bojkotu stanowi ze swej istoty przejaw utrudniania dostępu do rynku. Z punku widzenia treści art. 15 ust. 1 pkt 2 u.z.n.k. utrudnianie powinno się rozumieć jako działanie, w wyniku którego dochodzi do znaczącego wyłączenia możliwości dokonywania zakupu lub sprzedaży. Zastrzec jednak należy, że nie można każdego zachowania o domniemanym charakterze bojkotu potraktować jako formy utrudniania dostępu do rynku, gdyż naruszałoby to normatywny cel ustawy. Czyn bojkotu jest w tym znaczeniu jedynie okolicznościa faktyczna. Tymczasem utrudnianie dostępu do rynku stanowi fakt. Dlatego wbrew ustawie byłoby przyjęcie, że domniemane zachowanie stanowi każdorazowo utrudnianie dostępu do rynku. Wbrew bowiem takiemu domniemaniu przesłanka utrudniania wymaga dowodu, tj. wykazania ograniczeń w zakresie możliwości dokonywania zakupu lub sprzedaży. Kierunek tej linii wykładni podzielono w poglądzie, w którym przytoczono zbliżoną zresztą argumentację. Zgodnie z tezą tam wyrażona, nakłanianie do bojkotu nie zawsze stanowi utrudnienie dostępu do rynku i brak podstaw, aby przyjąć takie domniemanie faktyczne ${ }^{37}$. Szerszy wywód w tej materii prowadzi do stanowiska, że nakłanianie do bojkotu należy rozpatrywać w wieloaspektowym wymiarze, nie zaś jedynie jako formy utrudniania dostępu do rynku, gdyż nawet i w tym przypadku nie zawsze te dwie figury prawne pozostają ze soba $\mathrm{w}$ ścisłym związku.

W podsumowaniu powyższych rozważań należy podzielić ostatecznie dominujący pogląd, zgodnie z którym granica prawna pomiędzy zakazanym nakłanianiem do bojkotu a dozwolonym rozpowszechnianiem informacji (opinii) o produktach lub usługach danego przedsiębiorcy pozostaje wysoce nieostra. W tej sytuacji kwalifikacja prawna bojkotu zależna będzie od spełnienia klauzuli generalnej, tj. sprzeczności z prawem lub dobrymi obyczajami $^{38}$.

\footnotetext{
${ }^{34}$ W tym kierunku Nowińska (2014): 354; Nowińska, Szczepanowska-Kozłowska (2018): 331.

${ }^{35}$ Zob. Nowińska, Szczepanowska-Kozłowska (2018): 330-331.

${ }^{36}$ Tak Mioduszewski, Sroczyński (2016): 677.

${ }^{37}$ Por. np. Marcisz (2015): 22-23.

38 Tak wyraźnie Nowińska (2014): 352; Nowińska, Szczepanowska-Kozłowska (2018): 328; Mioduszewski, Sroczyński (2016): 679.
} 


\section{KLASYFIKACJA GRANIC NORMATYWNYCH BOJKOTU}

Sformułowane w doktrynie poglądy stanowią gotowe uzasadnienie dla odpowiedzialności ponoszonej z tytułu naruszenia niezakłóconego prawa do swobodnego konkurowania, naruszonego na skutek bojkotu. Natomiast treść tej odpowiedzialności wyznacza zasadniczo art. 15 ust. 1 pkt 2 u.z.n.k. Odnosi się to również do norm kompetencyjnych konstruujących tryb postępowania w razie stwierdzenia wystapienia zjawiska bojkotu. Wyrażone przez przedstawicieli nauki poglądy znajduja nie tylko uzasadnienie normatywne i aksjologiczne, ale przede wszystkim są niezwykle istotne dla rozwiązania analizowanego proble$\mathrm{mu}$, biorąc już tylko pod uwagę ochronę interesu przedsiębiorcy bojkotowanego.

Postulowane w doktrynie kryteria kwalifikowania pewnych czynów nieuczciwej konkurencji jako przejawów bojkotu można ujać zasadniczo w ramach siedmiu niezależnych argumentów. Po pierwsze, komunikat wynikajacy z bojkotu musi być zdolny do wywierania wpływu na adresata, gdyż zwykła zachęta do tego nie wystarczy, a w konsekwencji ma zmierzać do ograniczenia lub całkowitego wyeliminowania możliwości dokonywania transakcji przez określonych uczestników obrotu na rynku na skutek izolacji, co prowadzi do zerwania z nimi więzi gospodarczych ${ }^{39}$. Po drugie, wpływ bojkotu może pojawiać się w każdej niemal wiadomości przedsiębiorcy, w związku z czym różnicy pomiędzy nakłanianiem do bojkotu a zachęcaniem do zmiany kontrahenta należy upatrywać przede wszystkim w sposobie ukierunkowania takiego wpływu na ostateczny efekt gospodarczy ${ }^{40}$. Po trzecie, bojkot zawsze zawiera ładunek złej woli, ponieważ jego celem jest destabilizacja działalności określonego przedsiębiorcy, co jest tym samym wyrazem spełnienia przesłanki sprzeczności z prawem lub dobrymi obyczajami ${ }^{41}$. Po czwarte, ochrona rynku została rozszerzona na działania, które moga jedynie zmierzać do zorganizowania bojkotu, a w ten sposób nie obejmuje samych tylko faktycznych czynności wykonawczych polegających na odmowie zawarcia transakcji, na skutek czego dochodzi mimo wszystko do utrudnienia prowadzenia działalności gospodarczej ${ }^{42}$. Po piąte, musi dojść do rozpowszechniania nieprawdziwych lub wprowadzających w błąd informacji, które mogą utrudnić dostęp do rynku, wskutek czego nie dojdzie do nawiązania stosunków gospodarczych, a czynić to może wiele podmiotów indywidualnie i nawet bez porozumienia ${ }^{43}$. Dzieje się tak w szczególności, gdy treścią rozpowszechniania jest komunikat o nielegalnym wprowadzeniu produktu na rynek, który wskazuje na zamiar ewentualny i nielegalny charakter takiego rozpowszechniania ${ }^{44}$, z zastrzeżeniem porządkującym, że komentowany przepis nie znajduje zastosowania,

${ }^{39}$ Tak Mioduszewski, Sroczyński (2016): 628 i 672; Skoczny, Bernatt (2016): 550; Nowińska, Szczepanowska-Kozłowska (2018): 328.

${ }^{40}$ Zob. Mioduszewski, Sroczyński (2016): 679.

${ }^{41}$ Por. np. Skoczny, Bernatt (2016): 550.

${ }^{42}$ Zob. Mioduszewski, Sroczyński (2016): 676.

${ }^{43}$ Por. Nowińska (2014): 353; Mioduszewski, Sroczyński (2016): 677.

${ }^{44}$ Wyrok SA w Krakowie z 20 lipca 2007 r., I ACa 682/07, Lex nr 516555. 
jeżeli bojkotujący pozostaje w stosunku zależności wobec nakłaniającego do bojkotu ${ }^{45}$. Po szóste, podjęcie przez przedsiębiorcę środków zabezpieczajacych przeciwko bojkotowi świadczy wyraźnie o przekazie woli co do zachowywania się przez osoby trzecie w określony sposób, a przy tym ma zdolność - nawet potencjalnie - wywołania określonego skutku prawnego ${ }^{46}$. Podstawową konsekwencją tego stanu powstałego w związku z przedsięwziętymi przez przedsiębiorcę środkami jest odróżnienie siły nakłaniającego od użytych przez niego środków nakłaniających ${ }^{47}$. Po siódme, rozpowszechnianie nieprawdziwych informacji musi mieć określone podłoże, którym jest osiagnięcie korzyści lub wyrządzenie szkody, tj. zamiar bezpośredni, natomiast dalsza konsekwencja, jaką jest szerszy skutek utrudnienia dostępu do rynku, będzie objęta zamiarem wynikowym ${ }^{48}$.

\section{ZAKOŃCZENIE}

Przepis art. 15 ust. 1 pkt 2 u.z.n.k. jest niejasny i trudny do interpretacji. Wprawdzie doktryna i judykatura wypracowały pewne kryteria bojkotu, ale trudno ustalić dominujące stanowisko w tej kwestii. Rozbieżność ocen dotyczy zarówno podstawowych przesłanek definicji analizowanego pojęcia, jak i kwalifikacji bojkotu jako utrudniania dostępu do rynku. Istota wadliwości przepisu tkwi w braku możliwości uchwycenia wyraźnej różnicy pomiędzy pożądaną konsekwencją odpowiedzialności za przekazywanie nieprawdziwych i wprowadzających w błąd informacji, która nie powinna budzić wątpliwości w zderzeniu z aktualnymi regulacjami ustawowymi odnoszącymi się do deliktu bojkotu. Nie można również pozostawić poza zakresem definicji bojkotu rozpowszechniania nawet na pozór "neutralnych” informacji niezwiązanych z towarami i usługami, które mogą stanowić przejaw „ukrytego” bojkotu, skoro nie można wykluczyć ich wpływu na odmowę sprzedaży lub dokonanie zakupu.

Mając na uwadze przytoczone argumenty, delikt bojkotu należy oceniać na zasadzie reguł konstytutywnych, tj. okoliczności konkretnego przypadku. $\mathrm{Z}$ całą jednak pewnością zjawiska bojkotu nie można interpretować w znaczeniu pewnej kategorii norm generalnych przewidzianych wprawdzie przez ustawodawcę jako naganne czyny konkurencyjne, przy równoczesnym braku oparcia się na faktach. Sama zdolność czy zamiar bojkotowania nie wystarczą bowiem do kwalifikacji, że już z tego tylko tytułu doszło do tego czynu. Tak przedstawione argumenty przemawiają za rewizją stanowiska części doktryny i judykatury. W mojej ocenie przesłanki ziszczenia się czynu bojkotu w relacjach gospodarczych należy badać, przede wszystkim opierając się na tyle silnej i powszechnie dostępnej „eksplozji negatywnych informacji” przez

\footnotetext{
45 Tak Skoczny, Bernatt (2016): 549.

${ }^{46}$ Por. Mioduszewski, Sroczyński (2016): 676.

47 Zob. Nowińska (2014): 354.

48 Zob. Mioduszewski, Sroczyński (2016): 677.
} 
bojkotującego, że ich bezpośrednim skutkiem jest odmowa sprzedaży lub niedokonywanie zakupu u konkurenta, a w tym również dalsze nakłanianie do bojkotu przez kolejne podmioty.

Podzielając stanowisko części piśmiennictwa i orzecznictwa, uważam, że kwalifikacja prawna określonego czynu jako przejawu bojkotu powinna zostać przesądzona na podstawie trzech łącznie ziszczonych przesłanek. W pierwszej kolejności należy przede wszystkim zbadać, czy doszło do skutku faktyczne nakłanianie do bojkotu. W dalszej kolejności trzeba ocenić przesłankę, czy nakłanianie zawierało pakiet informacji nieprawdziwych lub wprowadzajacych w błąd (np. na zasadzie nieuczciwego zachwalania lub pomawiania, które $\mathrm{w}$ zderzeniu z ustawowymi regulacjami zawartymi w szczególności $\mathrm{w}$ art. 3 u.z.n.k. wyraźnie kwalifikuje, że granice tzw. uczciwego rozpowszechniania zostały przekroczone). W ten sposób rozpowszechnianie określonych informacji zmieni swój status na nieuczciwe nakłanianie. Ostatnią przesłanką wskazująca na delikt bojkotu jest bezsporny fakt odmowy sprzedaży albo niedokonywania zakupu u danego przedsiębiorcy ze względu na nieuczciwe nakłanianie.

Kierując się tak ustalonymi przesłankami, sąd orzekający nie powinien mieć wątpliwości, że podmiot bojkotujący jest winny. Z tego tytułu bojkotujący nie będzie mógł uwolnić się od odpowiedzialności za swój czyn pomimo trudności dowodowych w wykazaniu różnicy pomiędzy nieuczciwym nakłanianiem a dozwolonym rozpowszechnianiem określonych informacji. Dodatkowa korzyścią proponowanego rozwiązania powinno być również pozbawienie art. 15 ust. 1 pkt 2 u.z.n.k. waloru pustości normatywnej, a tym samym niskiej doniosłości praktycznej.

Mariusz Korcyl

Uniwersytet Jagielloński w Krakowie

mariusz.korcyl@doctoral.uj.edu.pl

https://orcid.org/0000-0002-5379-5404

Dominowska, J. (2013). Zbieg norm Prawa własności przemysłowej i ustawy o zwalczaniu nieuczciwej konkurencji. Państwo i Prawo 58(9): 80-94.

Kępiński, M. (2001). Glosa do wyroku SN z 2 lutego 2001 r., IV CKN 255/00. OSP 11: poz. 162.

Marcisz, P. (2015). Nazwane utrudnienia dostępu do rynku - znaczenie prawne wyliczenia z art. 15 u.z.n.k. Przegląd Prawa Handlowego 3: 15-24.

Nowińska, E. (2014). Ochrona funkcjonowania rynku na podstawie art. 15 ZNKU, [w:] M. Kępiński (red.), System prawa prywatnego. Tom 15: Prawo konkurencji. Warszawa: 338-354.

Nowińska, E., Szczepanowska-Kozłowska, K. (2018). Komentarz do art. 15 ZNKU, [w:] Ustawa o zwalczaniu nieuczciwej konkurencji. Komentarz. Warszawa: 293-331.

Nowińska, E., Vall, M. du (2005). Media w świetle konkurencji (Rozdział 13). Utrudnianie dostępu do rynku (pkt 3.6), [w:] J. Barta, R. Markiewicz, A. Matlak (red.), Prawo mediów. Warszawa. System informacji prawnej [Online]. Lex/el.

Nowińskia, E., Vall, M. du. (2008). Komentarz do art. 15 ZNKU, [w:] Ustawa o zwalczaniu nieuczciwej konkurencji. Komentarz. Warszawa: 187.

Nykiel-Mateo, A. (2009). Przesłanki uznania pomocy za sprzeczna ze wspólnym rynkiem (Rozdział III). Środki o charakterze politycznym (pkt 1.3.4), [w:] Pomoc państwa a ogólne środki interwencji w europejskim prawie wspólnotowym. Warszawa. System informacji prawnej [Online]. Lex/el. 
Skoczny, T., Bernatt, M. (2016). Komentarz do art. 15 ZNKU, [w:] J. Szwaja (red.), A. Jakubecki, M. Kępiński, M. Mozgawa, M. Niewęgłowski, M. Poźniak-Niedzielska, R. Skubisz, S. Sołtysiński, T. Skoczny, I Wiszniewska, M. Bernatt, E. Całka, J. Dudzik, S. Gogulski, K. Jasińska, J. Kępiński, A. Kubiak-Cyrul, Ustawa o zwalczaniu nieuczciwej konkurencji. Komentarz. Warszawa: 531-550.

Mioduszewski, M., Sroczyński, J. (2016). Komentarz do art. 15 ZNKU, [w:] M. Sieradzka (red.), M. Zdyb (red.), A. Michalak, M. Mioduszewski, J. Raglewski, J. Rasiewicz, J. Sroczyński, M. Szydło, M. Wyrwiński, Ustawa o zwalczaniu nieuczciwej konkurencji. Komentarz. Warszawa: 625-681.

Walaszek-Pyzioł, A., Pyzioł, W. (1994). Czyn nieuczciwej konkurencji (analiza pojęcia). Przegląd Prawa Handlowego 10: 1-8.

Żołyński, Ł. (2012). Ustawa o rozwiązywaniu sporów zbiorowych. Komentarz. Wzory pism. Warszawa.

\section{THE LEGAL BOUNDARIES OF BOYCOTTS \\ IN ECONOMIC RELATIONS}

\section{Sum mary}

The subject of this article is an attempt to verify whether the opinions found in the doctrine and judicature allow a given act which takes the form of a boycott to be clearly classified as a manifestation of unfair competition. This is particularly important in view of the fact that the legal boundary between the so-called permitted dissemination of certain information about a given entrepreneur and the prohibited incitement is difficult to determine. A separate issue in this area is to specify whether hindering market access and the associated phenomenon of torpedoing business activity must always bear the characteristics of an act of unfair competition, and in particular a boycott.

Keywords: unfair competition act; boycott; hindering market access; hindering business activities; equality of competition 
